\title{
The Effect of Morinda citrifolia L. Fruit Extract Supplemented in to Diluent Tris-Egg Yolk Toward the Abnormality of Goat's Spermatozoa after Freezing at $-80^{\circ} \mathrm{C}$
}

\author{
Apriani Herni Rophi ${ }^{1}$, Sri Rahayu ${ }^{2}$, Gatot Ciptadi ${ }^{*}$ \\ ${ }^{1}$ Master Program of Biology, Faculty of Mathematic and Natural Sciences, University of Brawijaya, Malang, Indonesia \\ ${ }^{2}$ Department of Biology, Faculty of Mathematic and Natural Sciences, University of Brawijaya, Malang, Indonesia \\ ${ }^{2}$ Faculty of Animal Husbandry, University of Brawijaya, Malang, Indonesia
}

\begin{abstract}
The aim of this research is to know the effect of diluent Tris-egg yolk medium added with Morinda citrifolia L. extract towards the sperms abnormality after storage at $-80^{\circ} \mathrm{C}$ for 24 hours. The extracts added in diluent Tris-egg yolk medium were $0 \%\left(P_{0}\right), 10 \%\left(P_{1}\right), 20 \%\left(P_{2}\right)$, and $30 \%\left(P_{3}\right)$. The result showed that the percentage of sperms abnormality in $P_{0}, P_{1}$, $P_{2}$, and $P_{3}$ were respectively $8.67 \%, 6.67 \%, 5.67 \%$, and $10 \%$. $P_{2}$ was the lowest percentage, while $P_{3}$ was the highest percentage of sperms abnormality. In addition, this research found twelve kinds of sperms abnormality divided into categories: major abnormality included the broke tail, absent head, detached head, dag defect, tapered head, proximal droplet, round head and abaxial; and minor abnormality included the coiled tail, shoe hook tail, bent tail, and distal droplet. It has been concluded that the allotment of $20 \%$ Morinda citrifolia L. extracts in Tris-egg yolk medium able to maintain the sperm morphology at $-80^{\circ} \mathrm{C}$ storage for 24 hours.
\end{abstract}

Keywords: goat, Morinda citrifolia L., post-thawing, spermatozoa.

\section{INTRODUCTION}

Goat, cattle and its production are very potential to be developed for filling domestic and export market. Big population in Indonesia increases the level of lamb consumption every year. Besides, goat's milk has a good prospect to replace cow's milk which is majority used in society [1]. Increasing of goat population through reproduction efficiency with biology reproduction technology providing in Livestock Research Center or other institution is one of the methods to fill goat consumption needs [2]. Sperm cells cryopreservation is the method to keep sperm cells in freeze circumstance, thus it can use anytime to support the application of reproductive technology for livestock [3].

The obstacle of cryopreservation is a freezing and thawing process decreasing the quality of spermatozoa [4]. The result of the previous study has been showed that post-thawing reduces motility, viability and enhances the abnormality in spermatozoa of cat [5], sheep [6], cow [7], and donkey [8]. Thawing causes drastic temperature alteration, thus it increases metabolism, augmenting the concentrate of free radicals [9]. Free radicals cause lipid peroxidation, thus

\footnotetext{
${ }^{*}$ Correspondence address:

Gatot Ciptadi

Email : ciptadi@ub.ac.id

Address : Faculty of Animal Husbandry, University of Brawijaya, Veteran Malang, Malang 65145.
}

damage spermatozoa cells and induce an autocatalytic reaction, which destructs the double bond of an unsaturated fatty acid constituent of phospholipid plasma membrane of spermatozoa [10]. The effect of the freezing process toward the increment of free radicals has been confirmed in 2001 using cow's spermatozoa; it showed the increasing of ROS during sperm production until post-thawing process [11]. Moreover, research in 2016 showed that a number of lipid peroxidation in postthawing semen is higher than fresh semen [5]. Awada and the relatives also presented that the effect of free radicals induced the rise of hydrogen peroxidation, lipid peroxidation, and reduce motility spermatozoa of Boer goat [12].

Lipid peroxidation has influenced the damage of structure and metabolism of spermatozoa so it can increase the abnormality of spermatozoa [13]. The drastic temperature alteration when freezing could affect the physiological condition of sperm cells like tail and the middle of the body around the head [14]. Based on Gogo, morphology is the important indicator to determine the quality of spermatozoa [15]. A previous study has been shown that there was a correlation between freezing with the increasing of spermatozoa abnormality [16].

Antioxidant addition in a diluent process can be applied to minimize damage due to free radical activity $[17,18]$. Some researchers have 
(Rophi et al)

been indicated that antioxidant addition such as vitamin $\mathrm{C}$, gluation, and $ß$-caroten in the diluent process could maintain the quality of freezing sperm cells through prevention of cell membrane damage and acrosome areas [18,19]. Morinda citrifolia L., a medical plant that is commonly found in Indonesia. The extract of $M$. citrifolia $L$. fruit has antioxidant activity [22]. It contains bioactive compounds like flavonoid, alkaloid, saponin, and triterpenoid [23]. In addition, it also contains 29.29 mg. mL ${ }^{-1}$ ascorbic acid [24]. Ascorbic acid is capable to give the hydrogen atom to the free radicals, secondary antioxidants. This mechanism is like with vitamin $\mathrm{E}$ work as an antioxidant and it can prevent the occurrence of chain reactions [23]. Ascorbic acid also plays to overcome free radicals, thus the spermatozoa membrane still save and reduce the abnormality [25]. Flavonoid alkaloid, saponin, triterpenoid, and ascorbic acid belongs to strong antioxidant compounds [23]. Because of the reasons above, this research was conducted to evaluate the abnormality of post-thawing spermatozoa in various dosages of $M$. citrifolia $L$. fruit extract in diluent $\mathrm{n}$ Tris-egg yolk medium.

\section{MATERIALS AND METHODS \\ Goat's Semen}

Goat's semen was collected from five goats aged 2-5 years old from The Center of Artificial Insemination Singosari, Malang. Semen collection was conducted two times in a week using Artificial Vagina (AV). First, we analyzed the quality of fresh semen before the semen was frozen. Animal procedures in this research were allowed with an ethics commission from Research Ethics Committee University of Brawijaya No. 875-KEP-UB.

\section{Morinda citrifolia L. Fruit Extract}

Fruit extract of $M$. citrifolia $L$. was made from simplicia fruit powder obtained from Material Medika, Batu-Malang. The extraction process was conducted using the maceration method based on Zin et al. [22]. Total of $200 \mathrm{~g}$ simplicia fruit powder, $400 \mathrm{~mL}$ hexane, 1,600 mL methanol, and ethyl acetate was used to make the extraction. From twice maceration process, we obtained $13 \mathrm{~g}$ crude extract of $M$. citrifolia L. fruit.

\section{Formation of Diluent Medium}

The making of diluent Tris-egg yolk medium was according to the work instruction of BBIB Laboratory, Singosari. Total of $100 \mathrm{~mL}$ diluent contained basic constituent of tris amino- methane $1.5 \%$, citric acid $0.9 \%$, lactose $1.4 \%$, egg yolk $20 \%$, raffinose $2.5 \%$ streptomycin 0.1 g. $100 \mathrm{~mL}^{-1}$, aquadest $80 \%$, and penicillin 0.1 g. $100 \mathrm{~mL}^{-1}$. The diluent added into semen was divided into 2 groups: diluent $A$ and diluent $B$. Diluent A consisted of Tris-egg yolk medium and M. citrifolia L. fruit extract, while diluent B consisted of diluent A with glycerol $7 \%$. In this research, the dosage of the extracts added into diluent $A$ were composed of $0 \%\left(P_{0}\right), 10 \%\left(P_{1}\right)$, $20 \%\left(P_{2}\right)$ and $30 \%\left(P_{3}\right)$. The volume of diluent $A$ and $B$ added into the semen were determined by work instruction of BBIB laboratory as the formulation below:

$V$ tot $=\frac{\text { vol. semen } x \text { semen concentration } x \text { vol. cryovials }}{\text { number of spermatozoa per crythe ovials }}$

Thus,

$$
\begin{aligned}
& V \text { diluent } B=\frac{V \text { tot }}{2} V \text { diluent } B=\frac{V \text { tot }}{2}, \\
& V \text { diluent } A=V \text { diluent } B-V \text { diluent } A \\
& V \text { diluent } A=V \text { diluent } B-V \text { diluent } A
\end{aligned}
$$

\section{Freezing Process}

Freezing process, equilibration, thawing and spermatozoa abnormality evaluation were conducted based on work instruction of BBIB Laboratory, Singosari. The diluent was conducted in two steps. First, adding diluent $A$ into fresh semen, this method was carried out in water bath at $37^{\circ} \mathrm{C}$. Second, adding diluent B when equilibration, equilibration was done after diluent $A$ was added. Semen was equilibrated in cool top at $5^{\circ} \mathrm{C}$ for 2 hours and followed by diluent $B$ addition twice: 1 hour after equilibration and 1 hour later after the first equilibration. Then the semen of the equilibration result was filled into $1 \mathrm{~mL}$ cryovials and put into $\mathrm{Mr}$ Frosty $^{\mathrm{TM}}$ for keeping in ultrafreezer with $-80^{\circ} \mathrm{C}$. Thawing was conducted in water bath $37^{\circ} \mathrm{C}$ for 30 seconds after 24 hours of the storage.

\section{Analysis of Spermatozoa Quality}

Evaluation of spermatozoa quality was carried out in twice: fresh semen evaluation and past thawing semen evaluation. The evaluation of fresh semen included: volume, concentration, $\mathrm{pH}$, individual motility, viability, and abnormality, while post-thawing semen evaluation included: abnormality evaluation. Volume evaluation was carried out by observing directly in the scale of tube used when collecting the semen. Concentration evaluation was done by mixing $8 \mu \mathrm{L}$ semen with $4 \mu \mathrm{L} \mathrm{NaCl}$ and then poured into cuvet to 
analyze using a spectrophotometer. Evaluation of $\mathrm{pH}$ was conducted by dripping $5 \mu \mathrm{L}$ of semen on the litmus paper. The result of the litmus paper was matched with the provided color scale. Individual motility evaluation was performed by dripping $5 \mu \mathrm{L} \mathrm{NaCl}$ and $5 \mu \mathrm{L}$ semen on the preparation object glass and then observed using a microscope. Viability evaluation was carried out by dripping $10 \mu \mathrm{L}$ semen and $10 \mu \mathrm{L}$ eosin-nigrosin on the preparation object glass and then it was mixed, swabbed, and left until dry. After that, we counted the spermatozoa with the light microscope and hand counter. Spermatozoa that absorbed the color was dead, whereas the spermatozoa that did not absorb color was alife. Abnormality evaluation in fresh semen was done by adding $5 \mu \mathrm{L}$ semen and $5 \mu \mathrm{L}$ eosin-nigrosin, whereas the evaluation of post-thawing semen was carried out by adding $10 \mu \mathrm{L}$ semen and $10 \mu \mathrm{L}$ eosin-nigrosin; the mixture of semen and eosinnigrosin then swabbed and left. The observation was performed using a light microscope (Olympus, Tokyo, Japan) with magnification at $400 x$ for evaluation of motility and viability, whereas magnification at $1000 x$ was used to evaluate abnormality. Abnormal spermatozoa counting was conducted as many as 200 cells using hand counter [26].

Data of fresh semen obtained were analyzed statistically with one-way ANOVA. If there was significant differentiation, it was continued by Least Significant Difference (LSD) and showed in average and deviation standard, while data of abnormality kinds were showed descriptively.

\section{RESULTS AND DISCUSSION}

\section{Quality of Fresh Sperm Cells}

Fresh semen was analyzed in macroscopic and microscopic way for knowing the first quality of semen that would determine the degree of dilution. The result showed in Table 1.

Table 1. Evaluation of Fresh Semen

\begin{tabular}{lc}
\hline \multicolumn{1}{c}{ Parameter } & Average \\
\hline Volume $(\mathrm{mL})$ & $1.87 \pm 0.24$ \\
Concentration $\left(10^{6} \cdot \mathrm{mL}^{-1}\right)$ & $2.543 \pm 796.39$ \\
$\mathrm{pH}$ & $6.6 \pm 0.08$ \\
Individual motility (\%) & $43.33 \pm 4.08$ \\
Viability (\%) & $74.67 \pm 2.50$ \\
Abnormality (\%) & $5.33 \pm 0.44$ \\
\hline
\end{tabular}

According to the fresh semen evaluation, $\mathrm{pH}$ and viability were belong to good fresh semen criteria [27]. The result of volume, concentration, and abnormality of fresh semen evaluation was indicated as the value that can be processed to frozen. However, individual motility evaluation had a low percentage. The previous study in 2016 mentioned only fresh semen has a volume between 1.0 and $2.0 \mathrm{~mL}$ with concentration more than $2.5 \times 10^{9}$ spermatozoa. $\mathrm{mL}^{-1}$, motility $>75 \%$ and normal spermatozoa $>85 \%$ used for cryopreservation [28]. Nevertheless, based on the buffalo sperm research conducted in 2006, the freezing process decreased the spermatozoa motility $22.67 \%$ [29], the motility has also decreased by $12 \%$ in grouper [30]. However, the post-thawing spermatozoa motility $20 \%$ can be used for artificial insemination [31]. The motility of fresh semen in this research still could be used in the next process.

\section{Morphology Structure of Post-Thawing Semen}

Abnormal morphology of spermatozoa related with the fertility of livestock. Moreover, freezing process caused cells damage and the ability of the fertilization was lower than fresh semen [32]. Table 2 showed the different of fresh semen abnormality between post-thawing semen given extract of $M$. citrifolia $L$. fruit. According to Table 2, the percentage of the abnormality increased from fresh to postthawing semen, $P_{0}, P_{1}, P_{2}$, and $P_{3}$, respectively. The comparison of post-thawing semen presented that $\mathrm{P}_{2}$ had a low abnormality of $5.67 \%$, whereas $\mathrm{P}_{3}$ had a high abnormality of $10 \%$. The lowest abnormality rate in $\mathrm{P}_{2}$ had a value which was not much different from the fresh semen abnormality value with a percentage of $5.33 \%$.

Table 2. Spermatozoa Abnormality in Fresh Semen and Post-thawing Semen in Various M. citrifolia L. Fruit Extract Dosage

\begin{tabular}{ccccc}
\hline \multicolumn{5}{c}{ Spermatozoa Abnormality (\%) } \\
\hline \multirow{2}{*}{$\begin{array}{c}\text { Fresh } \\
\text { semen }\end{array}$} & $\mathbf{P}_{\mathbf{0}}$ & $\mathbf{P}_{\mathbf{1}}$ & $\mathbf{P}_{\mathbf{2}}$ & $\mathbf{P}_{\mathbf{3}}$ \\
\cline { 2 - 5 } $5.33 \pm 0.44$ & $8.67 \pm 0.50$ & $6.67 \pm 0.58$ & $5.67 \pm 0.35$ & $10.00 \pm 0.90$ \\
\hline
\end{tabular}

Abnormality percentage of spermatozoa increased after the freezing process. The increment of abnormality percentage could be caused by cold shock [33]. Garner and Hafez also mentioned that the enhancement of the processes during the storage and the reducement of the temperature quickly increase the percentage of abnormality [34]. Cold shock caused by the freezing and rethawing process gain free radicals that could cause lipid peroxidation decreasing spermatozoa quality [12]. The increment of free radicals during the process freezing and thawing also decreased the spermatozoa motility [11]. There was a negative correlation between spermatozoa motility and 
abnormality; high abnormality reduced the spermatozoa motility [35]. In addition, the effect of the freezing process toward the reducement of spermatozoa abnormality has been shown in previous researches in Baung [35], cat [5], donkey [8], and cow [7].

From the post thawing evaluation, there was reducement of abnormality percentage in $\mathrm{P}_{0}$ to $\mathrm{P}_{3}$ treatment. It indicated that semen with extract of $M$. citrifolia L. fruit had lower abnormality than semen without $M$. citrifolia L. fruit extract. $P_{2}$ treatment had the lowest abnormality, it meant that $20 \%$ M. citrifolia L. fruit extract effective to reduce abnormality because of free radical increment during the process.

Fruit extract of $M$. citrifolia L. contains antioxidant compounds such as vitamin C, flavonoid, alkaloid, saponin, triterpenoid, and phenol that can prevent lipid peroxidation. Antioxidant compounds like flavonoid and 2,2diphenyl-1-picrylhydrazyl (DPPH) can give hydrogen atom to reduce DPPH radical. Next aryl radical of flavonoid resonate and give back hydrogen atom to DPPH radical. The complex between antioxidant and DPPH balance the stability and potential reaction of its molecule structure [23]. Based on the mechanism, antioxidant compounds has a stable characteristic in radical structure [36]. In addition, Nugraheni et al stated that constitute vitamin $C$ in $M$. citrifolia $L$. fruit extract has played as an antioxidant to overcome free radicals so it could save the cell membrane of spermatozoa and reduce the abnormality [25].

The rule of vitamin $C$ in $M$. citrifolia $L$ fruit extract as the antioxidant compound can donor an electron to form semi dehydroascorbate which is not reactive, then it disproportionate to form dehydroascorbate which is not stable. Dehydroascorbate will be degraded to form oxalic acid and treonate acid [37]. Previous studies have confirmed that the addition of antioxidant compound could reduce the free radical and lipid peroxidation in sheep. In Boer goat, it was approved that the value of Malondialdehyde (MDA) in semen added with antioxidant compounds (ascorbic acid, BHT, hypotaurine, and cysteine) was lower than semen without antioxidant. It was also mentioned that antioxidant addition could suppress spermatozoa abnormality [18].

There was an increment of abnormality percentage in $\mathrm{P}_{3}$ treatment. It meant that the addition of fruit extract dosage increased the abnormality. It might indicate that high dosage could give a negative impact on the spermatozoa. It was related to Rahardhianto et al. that adding the high concentrate mixture was not suitable with spermatozoa medium because spermatozoa could metabolize maximum if the diluent was in isotonic [39]. The cell membrane has semipermeable characteristic so both hypertonic and hypotonic will influence the water transportation through membrane cell and damage the integrity of the cell [40]. Cahyadi et al have mentioned that high dosage of addition bioactive compounds like flavonoid and alkaloid reduced the quality of spermatozoa [33] Moreover, a high concentration of ascorbic acid could accelerate the fructolysis and lactic acid accumulation and reduce $\mathrm{pH}$ [41]. Besides, lactic acid also had a toxic effect on the spermatozoa and furthermore caused spermatozoa morphological damage [42].

Table 3. Types of Abnormalities in Fresh Semen and Post-thawing Semen

\begin{tabular}{|c|c|c|c|c|c|}
\hline \multirow{2}{*}{ No. } & \multirow{2}{*}{ Fresh semen } & \multicolumn{4}{|c|}{ Post-thawing semen } \\
\hline & & $P_{0}$ & $\mathbf{P}_{1}$ & $\mathbf{P}_{2}$ & $\mathbf{P}_{3}$ \\
\hline \multicolumn{6}{|c|}{ Major abnormality } \\
\hline 1 & Broke tail & Broke tail & Broke tail & Broke tail & Broke tail \\
\hline 2 & - & Deteched head & Deteched head & Deteched head & Deteched head \\
\hline 3 & - & Absent head & Absent head & Absent head & Absent head \\
\hline 4 & dag defect & - & dag defect & - & - \\
\hline 7. & - & Round head & - & - & - \\
\hline 8. & - & Abaxial & - & - & - \\
\hline \multicolumn{6}{|c|}{ Minor abnormality } \\
\hline 9. & Coiled tail & Coiled tail & Coiled tail & Coiled tail & Coiled tail \\
\hline 10. & Shoehook tail & Shoehook tail & Shoehook tail & Shoehook tail & Shoehook tail \\
\hline
\end{tabular}




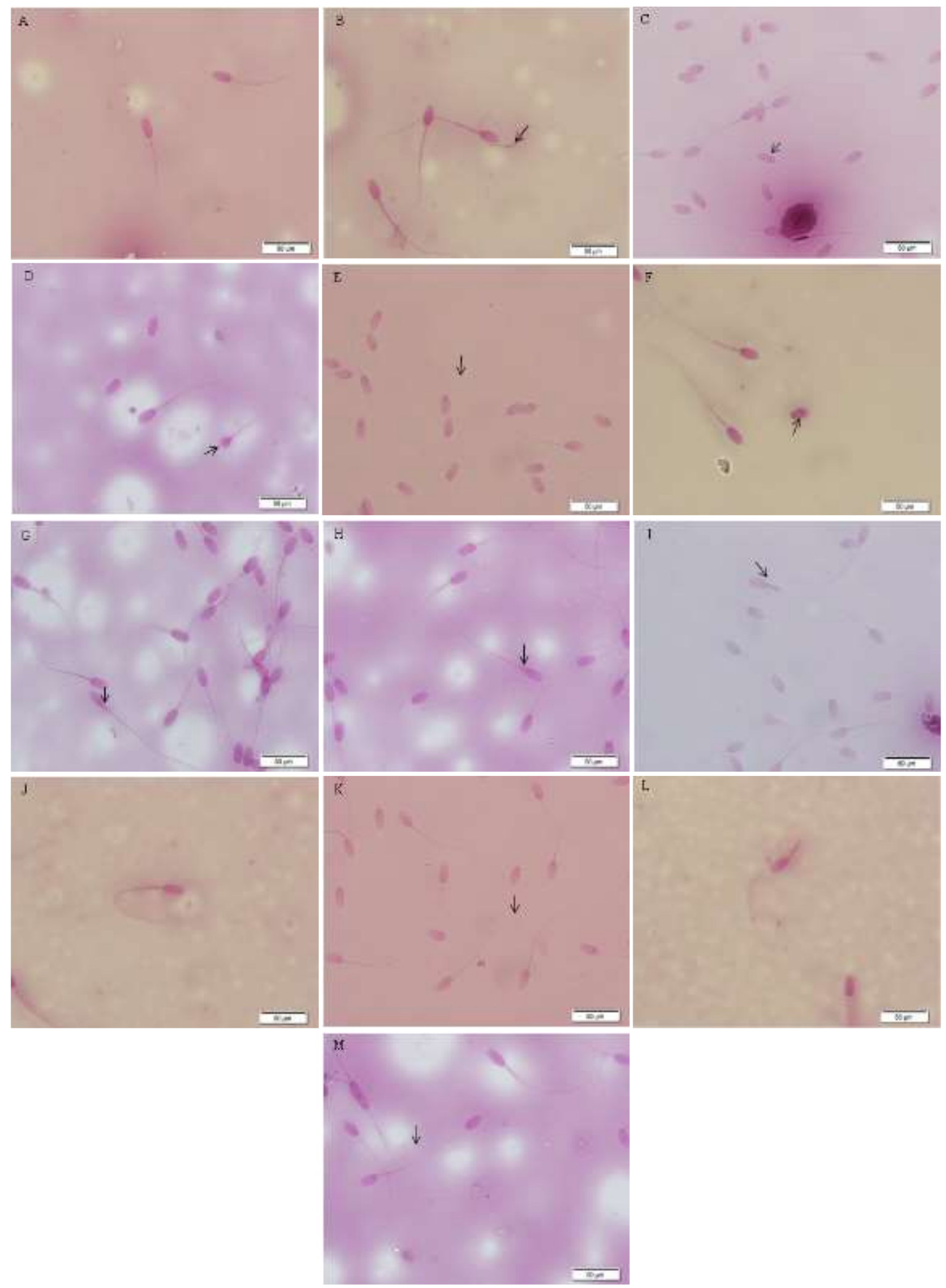

Figure 4. The Observation of Morphology Structure of Goat's Spermatozoa using Olympus BX53 Microscope with magnification at 1000x : (A) normal structure of spermatozoa (B) absent head, (C) tapered head, (D) round head, (E) broke tail, (F) deteched haid, (G) abaxial, (H) proximal droplet, (I) dag defect. Structure of minor abnormalities : (J) shoehook tail, (K) coiled tail (L) bent tail (M) distal droplet. 
(Rophi et al)

The addition of antioxidants compounds in high dosage have been reported that could be prooxidant causing oxidation inside the body $[41,42]$. The reaction between unsaturated fatty acid of spermatozoa cell membrane with excess oxygen has caused irreversible damage to the cell membrane [45]. The broken cell membrane increase abnormality of spermatozoa [46]. The last study using pome fruit extraction has also been showed that the addition of $50 \%$ fruit extract in the diluent medium could enhance the abnormality [47].

According to Table 3, there were 12 abnormalities in goat's sperm cells, and it was divided into two groups: major abnormality like broke tail, absent head, detached head, dag defect, tapered head, proximal droplet, round head, and abaxial; and minor abnormalities like coiled tail, shoe hook tail, bent tail, and distal droplet [5]. Each of abnormalities could be seen in Figure 4. Po had highest abnormality variations, 10 , while $P_{3}$ was in lowest position with 5 variations. $P_{0}$ also had the highest number of major variation with 7 variations, while $P_{3}$ was also in the lowest position with 3 variations. In minor variation term, $P_{0}$ and $P_{3}$ were in the highest and lowest position respectively. Abnormalities variations like broke tail, coiled tail, and shoe hook tail were mostly found in all of the samples.

$P_{0}$ had the most number of abnormality variations. It might be $P_{0}$ could not obtain the additional antioxidant maintaining the plasma membrane structure from free radicals that came from cold shock during the freezing process. Freezing and thawing process in the cryopreservation process have increased the spermatozoa morphology abnormality [4,35]. According to the result, broke tail, detached head, coiled tail, and shoe hook tail were found in all post-thawing treatments. This result was in line with the last study that the damage after freezing was bent tail, coiled tail, cracked (broken) tail, and damage (detached head), and it also has shown that abnormalities mostly found after cryopreservation was major abnormalities [7]. Even though $\mathrm{P}_{3}$ had the lowest abnormality variations (Table 3 ), but the intensity was highest is spermatozoa samples (Table 2).

Base on Chenoweth, the grouping major and minor abnormalities was based on their impact on male fertility. Major abnormality has big effected fertility, while minor abnormality has a small effect on fertility [48]. According to Table 3. $\mathrm{P}_{1}, \mathrm{P}_{2}$, and $\mathrm{P}_{3}$ treatment (added by $M$. citrifolia $\mathrm{L}$. fruit extract) had a smaller number of major abnormality than $\mathrm{P}_{0}$ (without $M$. citrifolia $L$ fruit extract). It indicated that the addition of $M$. citrifolia $L$. fruit extraction diluent medium could maintain the spermatozoa rather than without M. citrifolia $\mathrm{L}$. fruit extract.

The average abnormality percentage generated in each treatment was still belonged to normal, not more than $10 \%$, and still could be used for fertilization. Susilawati has mentioned that the percentage of normal morphology in the semen sample appropriate to the percentage of the motility [32]. According to Garner and Hafez percentage of good spermatozoa abnormalities for artificial insemination was 5 - 20\% [34].

\section{CONCLUSION}

There were 12 types of abnormalities found in this research, it was divided into 2 groups: major abnormality included broke tail, absent head, detached head, dag defect, tapered head, proximal droplet, round head, and abaxial; and minor abnormality included coiled tail, shoe hook tail, bent tail, and distal droplet. The highest percentage of post-thawing abnormality was $P_{3}$, while the lowest was $P_{2}$, thus $20 \% M$. citrifolia $L$ fruit extract addition in diluent Tris-egg yolk medium was the best concentration to maintain the normal morphology goat's sperm cells postthawing.

\section{ACKNOWLEDGEMENT}

The authors wish to thank the Indonesia Endowment Fund for Education (LPDP) which has provided grant funds to carry out this research.

\section{REFERENCES}

[1] Rusdiana, S., L. Praharani, U. Adiati. 2014. Prospek dan strategi perdagangan ternak kambing dalam merebut peluang pasar dunia. Agriekonomika. 3(2). 203-222.

[2] Putu, I.G. 2003. Aplikasi teknologi reproduksi untuk peningkatan performans produksi ternak kerbau di Indonesia. WARTAZOA. 13(4). 172-180.

[3] Gazali, M., S.N. Tambing. 2002. Ulasan: kriopreservasi sel spermatozoa. Hayati. 9(1). 27-32.

[4] Shi, L., Y. Ren, H. Zhou, G. Hou, W. Xun, W. Yue, C. Zhang, R. Yang. 2014. Effect of rapid freezing-thawing techniques on the sperm parameters and ultrastructure of Chinese Taihang Black Goat Spermatozoa. Micron. 57. 6-12.

[5] Prochowska, S., W. Nizanski, A. Partyka. 2016. Comparative analysis of in Vitro char- 
asteristics of fresh and frozen-thawed urethral and epididymal spermatozoa from cats (Felis domesticus). Theriogenology. 86. 2063-2072.

[6] Arando, A., A. Gonzalez, J.V. Delgado, F.A Arrebola, C.C Perez-Marin. 2017. Storage temperature and sucrose concentrations affect ram sperm quality after vitrification. Anim. Reprod. Sci. 18. 175-185.

[7] Khalil, W. A., M. A. El-Harairy, A.E.B. Zeidan, M. A.E. Hassan, O. Mohey-Elsaeed. 2012. Evaluation of bull spermatozoa during and after cryopreservation: structural and Ultrastructural Insights. Int. J. Vet. Sci. Med. 6. S49-S56.

[8] Demyda-Peyras, S., M. Bottrel, D. Acha, I. Ortiz, M. Hidalgo, J.J. Carrasco, V. GomezArrones, J. Gosalvez, J. Dorado. 2018. Anim. Reprod. Sci. 193: 201-208.

[9] Siregar, P. 1992. Metabolit oksigen radikal bebas dan kerusakan jaringan. Cermin Dunia Kedokteran. 80. 112-115.

[10] Maxwell, W.M.C., P.F. Watson. 1996. Recent progress in the preservation of ram semen. Anim. Reprod. Sci. 42. 55-65.

[11] Chatterjee, S., C. Gagnon. 2001. Production of Reactive Oxygen Species by spermatozoa undergoing cooling, freezing, and thawing. Mol. Reprod. Dev. 59. 451-458.

[12] Basim, A.J., M. Mackenzie-Bell, M.M. Buhr. 2009. Reactive Oxygen Species and Boer sperm function. Biol. Reprod. 81. 553-561.

[13] Alawiyah, D., M. Hartono. 2006. Pengaruh penambahan vitamin $\mathrm{E}$ dalam bahan pengencer sitrat kuning telur terhadap kualitas semen beku kambing Boer. J. Indon. Trop. Anim. Agric. 31(1). 8-14.

[14] Susilawati, T. 2013. Pedoman inseminasi buatan pada ternak. University of Brawijaya Press. Malang.

[15] Gago, C., P. Sanches, F. CH. Yeung, L. Tablado, T.G. Cooper, C. Soler. 1998. Standardization of sampling and staining methods for morphometric evaluation of sperm heads in the Cynomolgus Monkey (Mf) using Computer Assisted Image Analysis. Int. Androl. 21(3). 169-176.

[16] Gunawan. 2004. Pengaruh media pengencer terhadap kualitas spermatozoa beku Sapi PO. National Seminar of Animal Husbandry and Veterinary Technology 2004. Available at: peternakan.litbang.pertanian.go.id/fullteks/semn as/pro04-13.pdf.
[17] Ball, B.A., V. Medina, C.G. Gravance, J. Baumber. 2001. Effect of antioxidants on preservation of motility, viability, and acrosomal integrity of equine spermatozoa during storage at $5^{\circ} \mathrm{C}$. Theriogenology. 56. 577589.

[18] M.A. Akeel, H. Wahid, Y. Rosnina, Y.M. Goh, M. Ebrahim, F.M. Nadia. 2012. Effect of antioxidants on post thaw microscopic, oxidative stress parameter and fertility of Boer goat spermatozoa in Tris Egg-Yolk Glycerol Extender. Anim. Reprod. Sci. 136. 55-60.

[19] Herdis, I. Kusumo, M. Surachman, M. Rizal, I.K. Sutama, I. Inounu, B. Purwantara, R.I. Arifiantini. 2002. Peningkatan kualitas semen beku domba garut melalui penambahan $\alpha$-tokoferol ke dalam pengencer Susu Skim Kuning Telur. Jurnal Ilmu Ternak Veteriner. 7. 12-17.

[20] Rizal, M., M.R. Toelihere, T.L. Yusuf, B. Purwantara, P. Situmorang. 2002. Efektivitas berbagai konsentrasi Glutation terhadap kualitas semen yang telah dibekukan pada Domba Garut. J. Biosains. 7. 22-28.

[21] Rizal, M. 2005. Efektivitas berbagai konsentrasi ß-karoten terhadap kualitas semen beku Domba Garut. J. Anim. Prod. 7.6-13.

[22] Zin, Z.M., A. Hamid, A. Osman. 2001. Antioxidative activity of extract from Mengkudu (Morinda citrifolia L.) root, leaf, and fruit. Food Chem. J. 78. 227-231.

[23] Mulyaningrum, U.A. 2010. Aktivitas Antioksidan ekstrak buah dan daun Mengkudu. Bachelor Thesis. Dept. Chemistry. Bogor Agricultural University. Bogor.

[24] Nandashri, P., K.K. Pawa, J. Kaewtubtim, C. Jeamchanya, C. Jansom, C. Sattaponpun. 2005. Nutraceunical properties of Thai "Yor", Morinda citrifolia, and "Noni" juice extract. J. Sci. Technol. 27. 580-586.

[25] Nugraheni, T., O.P. Astirin, T. Widiyani. 2003. Pengaruh vitamin $C$ terhadap perbaikan Spermatogenesis dan kualitas spermatozoa Mencit (Mus musculus (L.)) setelah pemberian ekstrak tembakau (Nicotiana tabacum (L.)). Biofarmasi. 1(1). 13-19.

[26] The Center of Artificial Insemination (BBIB) Singosari. 2009. Laboratoty work instruction. Ministry of Agriculture. Malang.

[27] Kostaman, T., S. Keman, Suanardi, Sutama. 2004. Penampilan reproduksi kambing peranakan Etawah betina yang dikawinkan dengan kambing Boer jantan. Agrosains. 17(3). 299-312. 
[28] Yodmingkwan, P., S. Guntaprom, J. Jaksamrit. 2016. Effects extenders on fresh and freezing semen of Boer goat. Agric. Agric. Sci. Proc. 11. 125-130.

[29] Crosier, A.E., B.S. Pukazhenthi, J.N. Henghali, J. Howard, A.J. Dickman, L. Marker, D.E. Wildt. 2006. Cryopreservation of spermatozoa from wild-born Namibian Cheetahs (Acinony jubatus) and influence of glycerol on cryosurvival. Cryobiology. 52. 169-181.

[30] Yusoff, M., B.N. Hassan, M. Ikhwanuddin, S.Md. Sheriff, F. Hashim, S. Mustafa, I.C.C. Koh. 2018. Succesful sperm cryopreservation of the brown-marbled grouper, Epinephelus fuscoguttatus using propylene glycol as cryoprotectant. Cryobiology. 81. 168-173.

[31] Inounu, I. 2014. Upaya meningkatkan keberhasilan inseminasi buatan pada ternak ruminansia kecil. WARTAZOA. 24(4). 201209.

[32] Susilawati, T. 2011. Spermatology. University of Brawijaya Press. Malang.

[33] Cahyadi, T.R.T., M. Christiyanto, E.T. Setiatin. 2016. Persentase hidup dan abnormalitas sel spermatozoa kambing Peranakan Etawah (PE) dengan pakan yang disuplementasi daun Binahong (Anredera Cordifolia (Ten.) Steenis). Anim. Agric. J. 5(3). 23-32.

[34] Garner, D.L., E.S.E. Hafez. 2000. Spermatozoa and seminal plasma. In: Hafez, B., E.S.E. Hafez (Eds). Reproduction in Farm Animals, $7^{\text {th }}$ Ed. Lippincot William and Wilkins. Philadelphia.

[35] Muchlisin, Z.A., M.N. Siti Azizah. 2009. Influence of cryoprotectants on banormality and motility of Baung (Mystus nemurus) spermatozoa after long-term cryopreservation. Cryobiology. 58. 166-169.

[36] Williams, B., Cuvelier W.M.E., Berset C. 1995. Use of a free radical method to evaluate antioxidant activity. Lebensmittelwissenschaft und Technology. 28. 2530.

[37] Suhartono, E, H. Fachir, B. Setiawan 2007. Kapita sketsa biokimia stres oksidatif dasar dan penyakit. Lambung Mangkurat University. Pustaka Benua. Banjarmasin.

[38] Santiani, A., S. Evangelista, N. Sepulveda, J. Risopatron, J. Villegas, R. Sanchez. 2014. Addition of superoxide dismutase mimics during cooling process prevents oxidative stress and improves semen quality parame- ters in frozen-thawed ram spermatozoa. Theriogenology. 82. 884-889.

[39] Rahardhianto, A., N. Abdulgani, N. Trisyani. 2012. Pengaruh konsentrasi larutan madu dalam $\mathrm{NaCl}$ fisiologis terhadap viabilitas dan motilitas spermatozoa ikan Patin (Pangasius pangasius) selama masa penyimpanan. Jurnal Sains dan Seni ITS. 1(1). 58-63.

[40] Souhoka, D.F., M.J. Mataluta, W.M.M. Nalley, M. Rizal. 2009. Laktosa mempertahankan daya hidup spermatozoa kambing Peranakan Etawah yang dipreservasi dengan plasma semen domba Priangan. Jurnal Veteriner. 10(3). 135-142.

[41] Sumarsono, T. 1998. Peningkatan kualitas spermatozoa kerbau lumpur dengan penambahan asam askorbat dalam pengencer semen beku. Master Thesis. Bogor Agricultural University. Bogor.

[42] Ridwan. 2009. Pengaruh pengencer semen terhadap abnormalitas dan daya tahan hidup spermatozoa kambing lokal pada penyimpanan suhu $5^{\circ} \mathrm{C}$. J. Agroland. 16(2). 187-192.

[43] Sabile, S., A.T Latief, M. Yususf, S. Firmiaty, M. Idrus, Zulkharanain, Nasriyanto. 2016. Pengaruh penambahan ekstrak buah Mengkudu (Morinda Citrifolia Linn) dalam pengencer terhadap motilitas spermatozoa pada semen cair Sapi Bali. Jurnal Aves. 10(2). 10-15.

[44] Mc. Nulty, H.P., J. Byun, S.F. Lockwood, R.F. Jacob, R.P. Mason. 2006. Differential effect of carotenoid on lipid peroxidation due to membran interactions: X-Ray diffraction analysis. Biochemica et biophysica Acta. 1768. 167-174.

[45] Feradis. 2009. Peranan antioksidan dalam pembekuan semen. Jurnal Peternakan. 6(2). 62-70.

[46] Veznic, Z., D. Svecova, A. Zajicova, Z. Reckova, J. Rubes. 2007. The interrelationship between, quality parameters of sperm before and after separation by gradient centrifugation. Vet. Med. 52(10). 423-429.

[47] El-Sheshtawy, I. Reda, G. A. El-Sisy, W. S. ElNatat. 2016. Effects of pomegranate juice in tris-based extender on cattle semen quality after chilling and cryopreservation. Asian Pasific J. Reprod. 5(4). 335-339.

[48] Chenoweth, P.J. 2005. Genetic sperm defect. Theriogenology. 64. 457-468. 